\title{
Collaborative Vibration: The Mythic Journey of A Coal Boy
}

\author{
Keywords \\ Eastern systemic thinking, Essayist film production, Mythopoetic narrative, Personal Myth, Social technology.
}

Acknowledging the Anthropocene crisis, my research examines myth and myth-making to reimagine the role of Claude Lévi-Strauss' bricoleur concept. Following Joseph M. Coll's Taoist and Buddhist systemic thinking inspired theory of sustainable transformation, the practice-led project evolves into the making of an essayist film that conveys a specific personal myth. My research reckons that a bricoleur should perceive mythmaking as an organic growing organisation that acquires intuition and posteriori knowledge. And focus on a narrative that evolves into the mythic identity of a piece of coal and a bar-tailed godwit corresponding to designated oppositional values and semiotic assets. Apart from the practitioner works of Stan Brakhage, Chris Marker and Adam Curtis, my research also dives into Elysia Crampton Chuquimia, Howie Lee and Yaksha's musical languages to explore the other narrative possibilities when re-examining history in a socially conscious manner. As the film soundtrack is also part of the myth-making production. My practice-led project inevitably evolves into the subject of the self as the production presents a negotiation through metaphors and signifiers concerning memory, history and experience. The filmmaking echoes a search for the wisdom of self-acceptance. It adopts Stephen Yablo's understanding of conceivability to generate and regenerate meaningful assets. Concepts are planted to grow into newer representations compromising posteriori knowledge and self-realisations, with informal syllogistic reasoning concerning the epistemological nature of imagination and the transformative structure of myth. The contextual knowledge of my research examines the subject of myth and myth-making through Jacques Lacan's theory of fantasy, Jungian analytical psychology and Claude Lévi-Strauss knowledge of structural linguistics. It adopts Lévi-Strauss' canonical myth formula concerning the missing discussion of experience, community, and the wilder contexts of shamanology. Maurice Merleau-Ponty's phenomenological body and Martin Heidegger's thoughts on the philosophy of technology concerning the body-to-technology relation and the notion of symbolic light and darkness. With critics on the instrumentalist stance of technology and Rene Descartes's modal metaphysics concerning Arnold Gehlen's conservative alert of mankind's debased condition of modern existence, my research proposes that myth-making is a necessary altruistic form of social technology that can transform experience into wisdom. Acknowledging that will is the priority for behaviour change. The production examines the Dao of myth and mythmaking as a specific technological answer to resolve David Attenborough's calling for a global transformation and collaboration in his book A Life of Our Planet. To further develop such a technology, my research seeks a systemic understanding of myth and myth-making. Therefore, my research hypothesis a wholistic and heuristic methodology, namely Daoist bricoleur. By experiencing a personal myth, I celebrate my Manchu and Chinese culture origin and the complexity of my upbringing. My research visits the endangered Manchu Ulabun storytelling tradition and reckons the film production rely on the structural establishment of critical mythic fragments founded on autobiography and social conventions. As a permanent resident of New Zealand born in a coal-mining town in eastern Inner Mongolia, China, with an unverifiable ancestral clan name related to Kangxi, Yongzheng and Qianlong Emperor of the Qing Dynasty and much more. 